\title{
Managing Access to Advanced Therapy Medicinal Products: Challenges
} for NHS Wales

Champion, A.R.; Lewis, S.; Davies, S.; Hughes, Dyfrig

\section{British Journal of Clinical Pharmacology}

DOI:

https://doi.org/10.1111/bcp.14286

Published: 01/06/2021

Peer reviewed version

Cyswllt i'r cyhoeddiad / Link to publication

Dyfyniad o'r fersiwn a gyhoeddwyd / Citation for published version (APA):

Champion, A. R., Lewis, S., Davies, S., \& Hughes, D. (2021). Managing Access to Advanced Therapy Medicinal Products: Challenges for NHS Wales. British Journal of Clinical

Pharmacology, 87(6), 2444-2449. https://doi.org/10.1111/bcp.14286

\footnotetext{
Hawliau Cyffredinol / General rights

Copyright and moral rights for the publications made accessible in the public portal are retained by the authors and/or other copyright owners and it is a condition of accessing publications that users recognise and abide by the legal requirements associated with these rights.

- Users may download and print one copy of any publication from the public portal for the purpose of private study or research.

- You may not further distribute the material or use it for any profit-making activity or commercial gain

- You may freely distribute the URL identifying the publication in the public portal ?
}

Take down policy

If you believe that this document breaches copyright please contact us providing details, and we will remove access to the work immediately and investigate your claim. 
Title: Managing Access to Advanced Therapy Medicinal Products: Challenges for NHS Wales

Authors: Champion $\mathrm{AR}^{1}$, Lewis $\mathrm{S}^{1}$, Davies $\mathrm{S}^{1}$, Hughes $\mathrm{DA}^{2}$

${ }^{1}$ Welsh Health Specialised Services Committee, Unit G1, Treforest Industrial Estate, Pontypridd, UK, CF37 5YL

${ }^{2}$ Centre for Health Economics and Medicines Evaluation, Bangor University, Ardudwy, Holyhead Road, Bangor, UK, LL57 2PZ

Corresponding Author: Dr Sian Lewis, Welsh Health Specialised Services Committee, Unit G1, Treforest Industrial Estate, Pontypridd, UK, CF37 5YL. Telephone: +44(0)1443 443443 E-mail: sian.lewis100@wales.nhs.uk

Running Head: Managing Access to Advanced Therapy Medicinal Products

Key words: Cell therapy, gene therapy, regenerative medicine, advanced therapies, cost-effectiveness

Acknowledgements: The authors would like to thank colleagues at the All Wales Therapeutics and Toxicology Centre for commenting on an earlier draft.

Conflict of Interest: AC, SL, SD are Assistant, Managing and Finance Directors of the Welsh Health Specialised Services Committee, respectively; SL, SD and DAH are members of the All Wales Medicines Strategy Group and the Advanced Therapies Wales Programme Board; SD is member of the NICE Highly Specialised Technology evaluation committee.

Contributions: AC, SL, SD and DAH contributed substantially to the conception and design of the work. All authors made contributions to the acquisition, analysis, or interpretation of data. AC drafted the paper and all authors revised it critically for important intellectual content, and gave their final approval of the version to be published. SL agrees to be accountable for all aspects of the work in ensuring that questions related to the accuracy or integrity of any part of the work are appropriately investigated and resolved. 


\begin{abstract}
Advanced Therapy Medicinal Products (ATMPs) which include gene and somatic-cell therapies and tissue-engineered medicines, have the potential to transform current care pathways by offering durable and potentially curative outcomes. However, they are exceptionally expensive, with prices exceeding $f 1 \mathrm{~m}$ per patient in some cases. With an expectation that a large number of ATMPs will soon gain marketing authorisation (global market is estimated to reach $f 9 \mathrm{bn}$ to $f 14 \mathrm{bn}$ by 2025), healthcare payers and providers face a number of challenges to facilitate patient access to this new category of medicines.

This viewpoint reflects on the experience of introducing ATMPs into the National Health Service in Wales where $f 1$ in every $f 200$ spent on medicines in Wales (2019/20) is expected to be on ATMPs for just 20 patients. Evidence to date makes it apparent that decisions regarding clinical and costeffectiveness, and the scale of the budget impact of implementing ATMPs creates both financial and service risks. Consequently, there are significant policy implications. A critical examination is made of the approaches taken for the health technology assessment and appraisal of ATMPs, the methods of payment and service impacts of these medicines, and the approach taken to horizon scanning and subsequent modelling of the financial impact over the next 10 years.
\end{abstract}




\section{Introduction}

Advanced Therapy Medicinal Products (ATMPs) that aim to repair, replace, regenerate and reengineer genes, cells and tissues have the potential to transform current care pathways by offering durable and curative outcomes. Interest in the development and use of ATMPs is growing, prompted by promising early results with chimeric antigen receptor (CAR) T-cell therapies for refractory or relapsed haematological malignancies.

There are currently 10 ATMPs available within the European Union [1] and, with more expected to gain market authorisation, concerns have been expressed about the significant cost to healthcare payers, including the National Health Service (NHS) in the UK. There is a risk that ATMPs will either not be affordable or other treatments and services may need to be displaced in order to fund them. In addition, healthcare services in the UK are not currently configured to accept, adopt and deploy these therapies routinely.

This viewpoint reflects on recent experience within the devolved NHS in Wales, where the Government has set out its intention for Wales to be at the forefront of the new opportunities that ATMPs present [2]. The context in Wales - where it is expected that $f 1$ in every $f 200$ spent on medicines in 2019/20 will be on ATMPs for 20 patients - is likely to be reflective of the wider NHS across the UK.

\section{Health Technology Assessment and Appraisal}

To date, the majority of ATMPs have been marketed with a narrow license indication and often for use in second or subsequent lines of treatment. Often HTA bodies have only phase I and II studies to assess their clinical effectiveness, and most studies are multicentre, open-label and lack comparator data [3]. In the absence of trial-based comparisons, there is increased reliance on indirect comparisons using historical controls, which introduces significant bias. Additional challenges in assessing the clinical effectiveness of ATMPs are the lack of long-term outcome data, including health-related quality of life and survival, and reliance on endpoints that may not be good surrogates for outcomes that matter to patients.

A critical feature of ATMPs is their price. Tisagenlecleucel has a UK list price of $£ 282,000$ for a onetime infusion, Strimvelis ${ }^{\circledR}$ costs $£ 594,000$ per patient, and autologous CD34+ cells encoding $\beta A-T 87 Q$ globin gene (Zynteglo ${ }^{\circledR}$ ) for beta thalassaemia costs over $f 1 \mathrm{~m}$ (Table 1). Onasemnogene abeparvovecxioi (Zolgensma ${ }^{\circledR}$ ) for spinal muscular atrophy is poised to enter European markets, with a current US price of $\$ 2.1 \mathrm{~m}$. Consequently, providers are faced with difficult decisions concerning their value for money, reimbursement and budget impact implications.

The first wave of ATMPs assessed by the National Institute for Health and Care Excellence (NICE) were recommended for use via the cancer drugs fund (CDF) and are mandated in NHS Wales (Table 1). Appraisals under the CDF process means that different value judgements have been made in terms of evidentiary standards and value for money. The standard incremental costs effectiveness ratio (ICER) threshold of $£ 20,000$ per quality-adjusted life year (QALY) (up to $£ 30,000$ exceptionally) is not followed routinely. For many treatments, the ICER is not calculable, and for others, a threshold of $£ 50,000$ per QALY is more often applied [4]. It is anticipated that some ATMPs with non-cancer indications may be 
evaluated via the NICE Highly Specialised Technologies route in future, which operates a threshold of up to $£ 300,000$ per QALY [5].

Some have commented on the unique features of ATMPs in terms of being more likely to be one-off treatments that are designed to be curative [6], and that these may warrant a different analytical approach. The application of the standard 3.5\% per annum discount rate for benefits, for instance, will reduce the net present value of the long-term effects of ATMPs and increase the ICER. Some diseases such as haematological malignancies may not present until later in life ( $>65$ years), and this may create a challenge in terms of defining the lifetime benefit a patient may gain from curative treatment, and risk an unintended age bias. However, all these challenges are encountered in the assessments and appraisals of other health technologies (such as, one-off curative surgery which may also be costly but associated with large health benefits). NICE has determined that its standard HTA methods and processes for considering the clinical- and cost-effectiveness are appropriate for ATMPs [7]. However, the Institute for Clinical and Economic Review in the USA published adaptations to its value assessment framework for potential cures and other treatments that qualify as "high-impact, single or short-term therapies" [8].

Economic evaluations of ATMPs conducted to date suggest that ICERs are generally high and associated with significant uncertainty and potential bias owing to methodological challenges caused by the paucity of data on long-term outcomes [9].

\section{Paying for ATMPs}

Current ATMPs are purchased via standard method of reimbursement with an upfront cost for the product irrespective of success or failure of the treatment. Innovative payment methods may need to be developed to manage and share risk to facilitate timely patient access while the evidence matures. Whilst a simple patient access scheme discount has been negotiated for all the NICE-approved ATMPs so far, it may be necessary or desirable to look at different ways of paying. Upfront payments provides reimbursement to the manufacturers of the full value of the ATMP, with all the financial risks placed on the NHS. Alternatives, such as annual payments over a defined period dependent on continued successful response to treatment, and outcomes-based contracting payment schemes are likely to feature in the near-future commissioning of ATMPs [10].

\section{Impact on Service Delivery}

The first wave of ATMPs has provided an opportunity to learn about the practical service delivery considerations related to these new technologies including:

- Logistics - the timing of cell collection, transportation, processing and re-implantation is critical.

- ATMP production - the harvesting and processing of a patient's cells for CAR T-cell therapy, for instance, is complex and can involve transportation and processing across more than one country.

- Delivery mechanism - the service delivery pathway is similar to autologous stem cell transplantation. The critical phases are patient preparation including any chemotherapy or drug treatment or prehab, treatment with the product and aftercare including management of complications. 
- Complications - CAR T-cell therapies can provoke a life threatening cytokine response syndrome requiring a period of emergency treatment in an intensive care environment. This creates an additional pressure on capacity in this area.

- Success rates - treatment success rates vary, axicabtagene ciloleucel achieved 1-year complete response rates of $40 \%$ [11]. A majority of patients will therefore still require standard of care, which may include salvage therapies and progression to palliative care.

- New line versus substitution - the first wave of treatments are a new line of treatment rather than substitution, thus providing limited opportunity to release resources and realise savings from current services.

- Centre capacity - there are a limited number of designated centres, but not all are in operation. Patient treatments are currently being prioritised by a national (UK) process and being allocated to treatment centres.

\section{Scanning the Horizon for New ATMPs}

Horizon scanning aims to support planning and priority-setting by increasing awareness of new and emerging health technologies. Developing an accurate financial projection is challenging, and horizonscanning activities can provide valuable intelligence on:

- Different options of how quickly the pipeline of new ATMPs will turn into approvals - the most likely scenario is a surge in the next five years, before reaching a steady state.

- The numbers of patients - this is extremely difficult without an understanding of the specific disease groups impacted by new ATMPs. However, a budget impact model will need to take into account that the numbers needing treatment may be greater in the early years as prevalent cases are gradually replaced by incident patients.

- Additional financial risks, including whether the place in therapy of the ATMP will change over time - experience of use and strategies to manage safety concerns may increase the likelihood of ATMPs being used earlier, even as first line therapy.

- Payment schemes - it is likely that the pricing structure used by industry will push towards upfront costs while benefits are likely to accrue in the long term.

- The associated NHS costs - the total costs to the service is likely to far exceed the drug acquisition costs. The total cost of CAR T-cell therapy, for instance, needs to also consider the costs associated with leukapheresis and lymphodepletion therapy, as well as the costs of managing adverse effects, which is significant with $44 \%$ of patients who received tisagenlecleucel in clinical trials requiring stays in the intensive care unit for cytokine release syndrome [12]. Advance knowledge of such costs are an important component of horizon scanning.

\section{Long Term Financial Forecasting for NHS Wales}

During 2018-19, NICE published four guidances on ATMPs, with total projected costs to NHS Wales of $£ 4.381 \mathrm{~m}$ in $2019 / 20$, rising to $f 6.924 \mathrm{~m}$ in $2020 / 21$. This represents $0.75 \%$ and $1.10 \%$ of the annual revenue budget for specialised services, and $0.48 \%$ and $0.70 \%$ of the annual NHS Wales medicines budget allocated to only $0.00063 \%$ of the population. There are currently over 959 companies worldwide developing ATMPs, with products being tested in 1052 clinical trials [13]. As many as 70 ATMPs could become available in the UK by 2024, although not all will progress to gaining marketing authorisation [14]. Accurate financial forecasting is therefore essential to plan future services, and to make provisions (or savings in other health services) in order to finance new and existing ATMPs. In 
practice there is greater certainty regarding the 1-year horizon as products are scheduled within the NICE 'forward look' timetable. Greater uncertainty is inevitable in longer term forecasting, as information on available treatments, their clinical indications and costs is very limited.

The results of a rudimentary model of the potential scale of the future (10-year) financial impact of ATMPs on the NHS Wales budget are depicted in Figure 1. This considers the cost of the ATMP including the cost of manufacturing, transport and supply; and the cost of care, including hospital admissions. The model assumes future ATMPs become available at a modest rate of up to 5 new products per annum, and include 1 rare disease, 3 cancer and 1 haematological indication. With the exception of the rare disease indication $(f 1 \mathrm{~m})$, the costs of new ATMPs are conservatively assumed to be $10 \%$ lower than existing products. Service costs are also decreased by $25 \%$ to reflect the new NHS England tariff price of $£ 92,000$ [15]. Whilst a tariff price reduces the degree of uncertainty, it is not clear whether this will be deliverable in practice or be reflective of actual costs, as it excludes the product, intensive care and preparatory treatment costs. The cumulative indicative costs reaches over f150m by year 10, and this has policy implications for the Welsh Government in terms of priorities and strategic transformation resources.

\section{Conclusions and recommendations}

The introduction of ATMPs undoubtedly creates new opportunities for providing new curative treatments and potentially wider benefits to the economy [16]. The Advanced Therapy Treatment Centres, which aim to provide the necessary commercial and NHS infrastructure required to facilitate the delivery of ATMPs to patients, represent one opportunity for the UK to be at the forefront of ATMP research and innovation.

However, these will depend critically on NHS resources, including workforce capacity for successful translation to clinical practice and improved patient outcomes. The scale of the financial challenge potentially presents a major financial risk over the next five to ten years. Consequently, there are significant policy issues arising, including the level at which payers of healthcare are willing to fund ATMPs, the methods of evaluation, the need to challenge how these treatments are priced by the pharmaceutical industry and what prioritisation trade-offs the NHS is willing to make in order to implement. There are significant uncertainties in terms of the pace of new approvals and the numbers of patients that may benefit from treatment. The current pipeline is concentrated on rarer diseases but may broaden over time with further financial and service risks associated with this. There is a need to develop alternative methods of managing costs, such as annuity or amortisation of payments over a fixed time-period, and innovative outcomes-based performance payments. 


\section{References}

1. European Medicines Agency. CAT monthly report of application procedures, guidelines and related documents on advanced therapies. EMA/CAT/54845/2020. 30 January 2020. Available at: https://www.ema.europa.eu/en/committees/cat/cat-agendas-minutes-reports [Accessed 16 February 2020].

2. Welsh Government. Advanced Therapies Statement of Intent. April 2019. Available at: https://gov.wales/sites/default/files/inline-documents/2019-04/190409\%20-\%20VG\%20\%20Advanced\%20Therapies\%20Statement\%20of\%20Intent\%20-\%20English.pdf [Accessed 9 December 2019].

3. Hatswell AJ, Freemantle N, Baio G. Economic Evaluations of Pharmaceuticals Granted a Marketing Authorisation Without the Results of Randomised Trials: A Systematic Review and Taxonomy. Pharmacoeconomics. 2017;35(2):163-176.

4. Wood EM, Hughes DA. The New and Non-Transparent Cancer Drugs Fund. Pharmacoeconomics. 2020;38(1):1-4.

5. National Institute for Health and Care Excellence. Interim Process and Methods of the Highly Specialised Technologies Programme. Available at:

https://www.nice.org.uk/Media/Default/About/what-we-do/NICE-guidance/NICE-highlyspecialised-technologies-guidance/HST-interim-methods-process-guide-may-17.pdf [Accessed 9 December 2019].

6. Drummond MF, Neumann PJ, Sullivan SD, Fricke FU, Tunis S, Dabbous O, Toumi M. Analytic Considerations in Applying a General Economic Evaluation Reference Case to Gene Therapy. Value Health. 2019;22(6):661-668.

7. Crabb N, Stevens A. Exploring the assessment and appraisal of regenerative medicines and cell therapy products. National Institute for Health and Care Excellence. Available at: https://www.nice.org.uk/media/default/about/what-wedo/science\%20policy\%20and\%20research/regenerative-medicine-study-march-2016.pdf [Accessed 9 December 2019].

8. Institute for Clinical and Economic Review. Valuing A Cure: Final White Paper and Methods Adaptations. November 2019. Available at: https://icer-review.org/material/valuing-a-cure-finalwhite-paper-and-methods-adaptations/ [Accessed 9 December 2019].

9. Lloyd-Williams H, Hughes DA. A Systematic Review of Economic Evaluations of Advanced Therapy Medicinal Products. Br J Clin Pharmacol. 2020.

10. Kefalas P, Ali O, Jørgensen J, Merryfield N, Richardson T, Meads A, Mungapen L, Durdy M. Establishing the cost of implementing a performance-based, managed entry agreement for a hypothetical CAR T-cell therapy. J Mark Access Health Policy. 2018;6(1):1511679.

11. Neelapu SS, Locke FL, Bartlett NL, Lekakis L, et al. Axicabtagene Ciloleucel CAR T-Cell Therapy in Refractory Large B-Cell Lymphoma. N Engl J Med. 2017;377(26):2531-2544.

12. Hernandez I, Prasad V, Gellad WF. Total Costs of Chimeric Antigen Receptor T-Cell Immunotherapy. JAMA Oncol. 2018;4(7):994-996.

13. Alliance for Regenerative Medicine. Quarterly Regenerative Medicine Sector Report Q3. 2019. Available at: https://alliancerm.org/?smd process download=1\&download id=5556 [Accessed 11 February 2020].

14. Davis H. Specialist Pharmacy Services Horizon Scanning Lead. Personal communication, 14 February 2020. 
15. NHS England. 2019/20 National Tariff Payment System. Available at: https://www.england.nhs.uk/pay-syst/national-tariff/2019-20-payment-reform-proposals/ [Accessed 11 February 2020].

16. Medicine Manufacturing Industry Partnership, 2016. Advanced Therapies Manufacturing Action Plan: Retaining and attracting advanced therapies manufacture in the UK. Available at: https://www.abpi.org.uk/media/1458/advanced-therapies-manufacturing-taskforce-report.pdf [Accessed 11 February 2020]. 
Table 1. Summary of NICE appraised ATMPs to date including projected financial forecast for 2019-21

\begin{tabular}{|c|c|c|c|c|c|}
\hline $\begin{array}{l}\text { NICE } \\
\text { /AWMSG } \\
\text { number }\end{array}$ & Therapy (trade name) $^{a}$ & Indication & $\begin{array}{l}\text { Total treatment } \\
\text { cost per patient }^{\mathrm{b}}\end{array}$ & $\begin{array}{l}\text { Estimated number } \\
\text { of eligible Welsh } \\
\text { patients (2019-21) }\end{array}$ & $\begin{array}{l}\text { Estimated total } \\
\text { cost }(2019-21)^{c}\end{array}$ \\
\hline HST7 & $\begin{array}{l}\text { Autologous CD34+ cells transduced with } \\
\text { retroviral vector that encodes for the } \\
\text { human ADA cDNA sequence (Strimvelis }{ }^{\circledast} \text { ) }\end{array}$ & $\begin{array}{l}\text { Adenosine deaminase deficiency-severe } \\
\text { combined immunodeficiency }\end{array}$ & $f 594,000$ & 1 every 5 years & $£ 237,600$ \\
\hline TA554 & Tisagenlecleucel (Kymriah ${ }^{\circledR}$ ) & $\begin{array}{l}\text { Relapsed or refractory B-cell acute } \\
\text { lymphoblastic leukaemia in people aged up } \\
\text { to } 25 \text { years }\end{array}$ & $£ 420,000$ & 2 & $f 840,000$ \\
\hline TA567 & Tisagenlecleucel (Kymriah ${ }^{\circledR}$ ) & $\begin{array}{l}\text { Relapsed or refractory diffuse large B-cell } \\
\text { lymphoma after } 2 \text { or more systemic } \\
\text { therapies }\end{array}$ & $£ 420,000$ & 13 & $£ 5,460,000$ \\
\hline TA559 & Axicabtagene ciloleucel (Yescarta ${ }^{\circledR}$ ) & $\begin{array}{l}\text { Diffuse large B-cell lymphoma and primary } \\
\text { mediastinal large B-cell lymphoma after } 2 \text { or } \\
\text { more systemic therapies }\end{array}$ & $£ 420,000$ & 13 & $f 5,460,000$ \\
\hline TA410 & Talimogene laherparepvec (Imlygic ${ }^{\circledR}$ ) & Unresectable metastatic melanoma & $£ 1,670$ per vial & unknown & $£ 1,670$ per vial \\
\hline $\begin{array}{l}\text { AWMSG non- } \\
\text { submission } \\
(2050)^{d}\end{array}$ & $\begin{array}{l}\text { Thymidine kinase cell therapy } \\
\left(\text { Zalmoxis }{ }^{\circledR}\right)\end{array}$ & $\begin{array}{l}\text { Adjunctive treatment in haploidentical } \\
\text { haematopoietic stem cell transplantation of } \\
\text { adult patients with high-risk haematological } \\
\text { malignancies }\end{array}$ & $\begin{array}{l}£ 150,000 \text { per } \\
\text { infusion }\end{array}$ & $\mathrm{n} / \mathrm{a}$ & $\mathrm{n} / \mathrm{a}$ \\
\hline HST11 & Voretigene neparvovec (Luxturna ${ }^{\circledR}$ ) & Inherited retinal dystrophies & £306,705 per eye & 4 & $£ 1,226,820$ \\
\hline TA467 & $\begin{array}{l}\text { Ex vivo expanded autologous human } \\
\text { corneal epithelial cells containing stem } \\
\text { cells }\left(\text { Holoclar }^{\circledR} \text { ) }\right.\end{array}$ & Limbal stem cell deficiency after eye burns & f80,000 per eye & 510 & $£ 800,000$ \\
\hline TA508 & Chondrosphere (Spherox ${ }^{\circledR}$ ) & $\begin{array}{l}\text { Symptomatic articular cartilage defects of } \\
\text { the knee }\end{array}$ & $£ 10,000$ & 20 & $f 200,000$ \\
\hline TA556 $^{\mathrm{e}}$ & Darvadstrocel (Alofisel ${ }^{\circledR}$ ) & Complex perianal fistulas in Crohn's disease & $£ 54,000$ & $\mathrm{n} / \mathrm{a}$ & $\mathrm{n} / \mathrm{a}$ \\
\hline ID968 $^{f}$ & $\begin{array}{l}\text { Autologous CD34+ cells encoding } \beta A- \\
\text { T87Q-globin gene }\left(Z y^{\prime} \text { teglo }^{\circledR} \text { ) }\right.\end{array}$ & $\begin{array}{l}\text { Beta thalassaemia in patients } 12 \text { years and } \\
\text { older who require regular blood } \\
\text { transfusions }\end{array}$ & $£ 1,120,000$ & $\mathrm{n} / \mathrm{a}$ & $\mathrm{n} / \mathrm{a}$ \\
\hline
\end{tabular}

${ }^{a}$ ATMPs that have been withdrawn from use in the EU include: ChondroCelect ${ }^{\circledR}$ (characterised viable autologous cartilage cells expanded ex vivo expressing specific marker proteins), Glybera ${ }^{\circledR}$ (alipogene tiparvovec), Maci ${ }^{\circledR}$ (matrix-applied characterised autologous cultured chondrocytes) and Provenge ${ }^{\circledR}$ (sipuleucel-T)

${ }^{b}$ Includes the cost of the therapy and, for CAR T-cell therapies, all other associated treatment costs (for example ICU provision, managing treatment side effects)

c Put into context, the population of Wales (2019) is 3,184,000; the total NHS costs of medicines, including primary care prescribing (2018/19) was $f 911.3 \mathrm{~m}$; the cost of hospital-prescribed medicines (2018/19), excluding cancer medicine was $£ 348.2 \mathrm{~m}$; and the cost of hospital-prescribed cancer medicines (2018/19) was $f 108.1 \mathrm{~m}$

${ }^{\mathrm{d}}$ Not approved for use in NHS Wales 
e Not recommended for use in NHS Wales

${ }^{f}$ Currently being appraised by NICE. Decision expected June 2020 
Figure 1. Projected costs and patients number for ATMP in Wales (2019/20 to 2028/29)
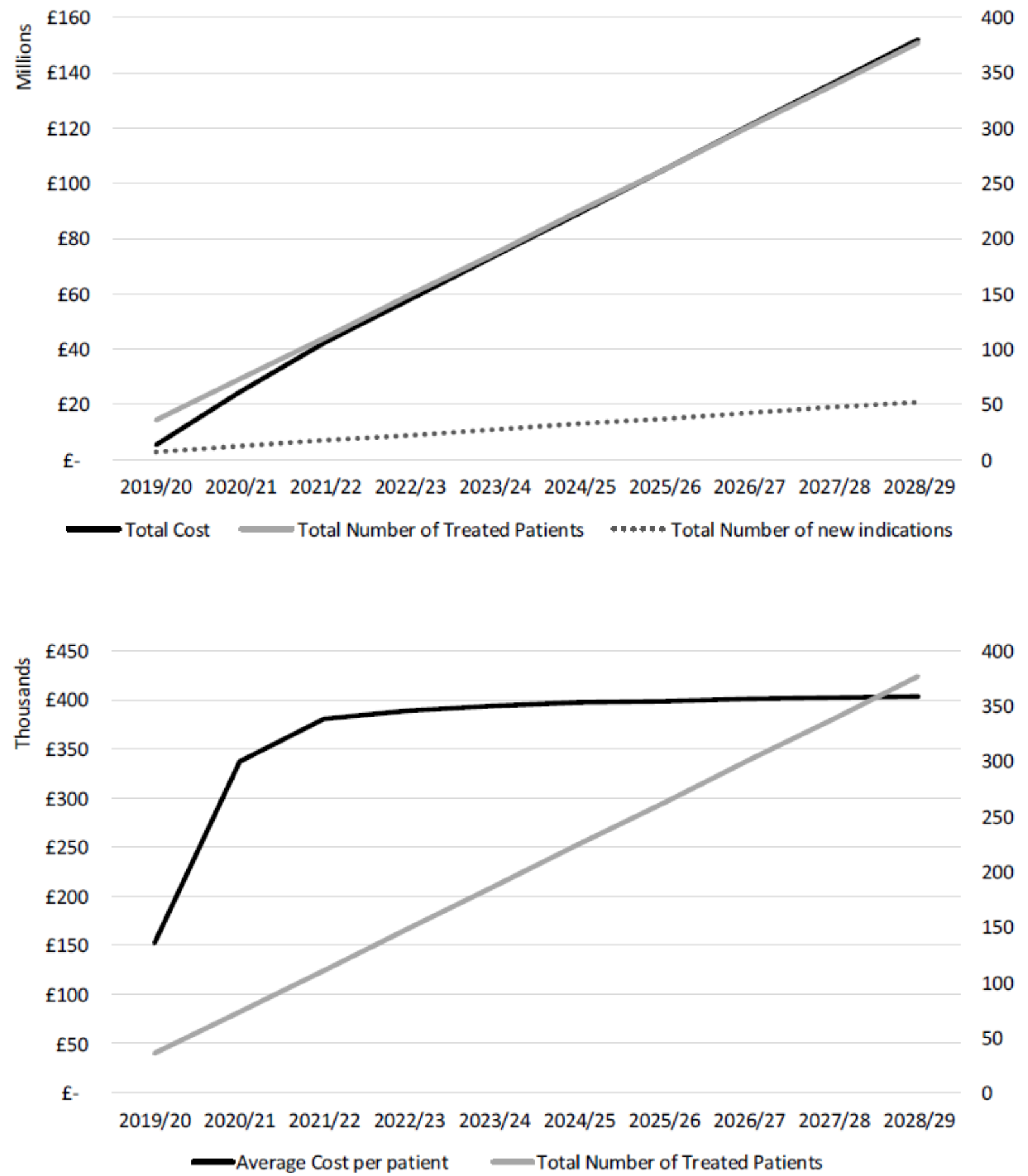

Legend: Projected total costs, patient numbers and new clinical indications for ATMP (upper panel); average cost per patient and total number of patients (lower panel). 